\title{
CONSTITUTIONAL AND LEGAL FRAMEWORKS FOR THE FORMATION AND FUNCTIONING OF THE ELECTRONIC GOVERNMENT SYSTEM IN UZBEKISTAN
}

\author{
Sanjar Sadikov, \\ an independent competitor of the Department of Theory and \\ History of State and Law of Tashkent State Universityof Law
}

http://dx.doi.org/10.26739/2573-5616-2018-3-1-13

\begin{abstract}
The article is devoted to the topical problem of IKT Constitution legal development of legislation by formation and activity of e-government. The authors considers acceptance of the Law about e-government has become a progressive step in improving the legislation of the country. The article review the features of the new Law about egovernment.
\end{abstract}

Key words: Constitution, e-government, legislation, Law about e-government.

The Constitution of the Republic of Uzbekistan establishes the right to receive information by appropriate norms. In particular, in Article 29 of the Constitution: "Everyone has the right to freedom of thought, speech and belief. Everyone has the right to seek, receive and impart any information, except against the existing constitutional order and other restrictions provided for by law" [1].

"Our urgent task, relevant today and for the future - is to ensure the effective functioning of the entire system of "Electronic Government"

Sh.Mirziyayev [2]

"Electronic government" is an organizational form of public administration that takes into account citizens' identities, which is intended to provide services to the public by state authorities, ensuring openness and transparency of the activities of public authorities and management using information and communication technologies. Currently, the use of information and communication technologies in public administration, in particular, the introduction of the "e-government" system, is one of the main ways to optimize the government process.In this direction, a number of organizational and legal measures are being implemented in the Republic of Uzbekistan, and to date more than 50 legislative acts regulate the introduction and use of information and communication technologies in the public and private sectors. 
In accordance with the Decree of the President of the Republic of Uzbekistan dated May 30, 2002, No.3080 "On the further development of computerization and the introduction of information and communication technologies", a number of tasks were defined, according to which the creation of modern safe and reliable national information bases, the development of the market of information resources and services, the phased transition of information exchange into electronic format, computerization and development of information and communication technologies and the introduction of their modern systems are identified as the most important polls [3]. In the Republic of Uzbekistan, in the normative legal acts, the term "electronic government" was first used in Resolution of the Cabinet of Ministers No.200 of June 6, 2002 "On measures to further improve the interaction of state and economic management bodies, state authorities in the field with legal entities and individuals with the use of information and communication technologies ": The program provided the following main directions of development of the software production industry: e specialized research, scientific and technical centers for software development; support of domestic software producers through the creation of a favorable tax and customs regime, as well as expanding their participation in nationwide programs to create egovernment, e-commerce, informatization of education, health, and other sectors of the economy; assistance in the export of software products produced by domestic companies".

Issues related to informatization of public administration are directly regulated by the Decree of the President of the Republic of Uzbekistan "On the Further Development of Computerization and the Implementation of Information and Communication Technologies", the Resolution "On Additional Measures for the Further Development of Information and Communication Technologies", Cabinet of Ministers Decrees "On Measures for Further Improvement interaction of state and economic management bodies, state power on the ground with legal them and individuals using information and communication technologies "and" On measures to further improve the activities of the government portal of the Republic of Uzbekistan on the Internet, taking into account the provision of interactive public services".Taking into account the fact that there are more than one hundred state bodies in the Republic of Uzbekistan, the process of streamlining more than one hundred thousand legal documents regulating the relations of society and state activity is underway, in addition, taking into account the need for consistent improvement of the "egovernment" system in all directions, in order to eliminate unnecessary, formally existing, overlapping public services, the formation of a unified base of public services, it is expedient for development of legislative acts. 
In accordance with the Resolution of the Cabinet of Ministers of the Republic of Uzbekistan, Resolution No. 256 of November 22, 2005, "On Improving the Regulatory and Legal Framework in the Sphere of Informatization" the Regulations on the Formation of State Information Resources and the Provision on the Procedure for the Creation of Information Systems of State Bodies were approved. The Regulations on the Procedure for the Creation of Information Systems of State Bodies determine the general requirements for the information systems of state bodies, the requirements for the procedure for their creation, as well as the responsibilities of state bodies when creating information systems of information systems, ensuring information security, forming state information resources, rights, duties and responsibilities relevant government bodies, streamlining issues related to liability, rights and interests of businesses and individuals in their use [4, P.355].

The Regulation on the procedure for the formation of state information resources defines the basic requirements for documenting information in state bodies, the procedure for the formation and use of state information resources, ensuring information security, rights, tasks and responsibilities of state bodies when creating information systems[5].

The concept of the introduction of the system "Electronic government"in the Republic of Uzbekistan, which gave a significant impetus to the development of the legal framework, was developed in accordancewith the Decree of the President of the Republic of Uzbekistan of October 16, 2012 No.4475 "On the establishment of the State Committee for Communications, Informatizationand telecommunication technologies of the Republic of Uzbekistan"and the Decree of the President of the Republic of Uzbekistan of March 21, 2012 No. 1730 "On measures for the further introduction and development of modern information and communication technologies". The concept defines the main directions of the introduction of the "e-government" system, the use of information technologies in the activities of state bodies in interaction with citizens, organizations, foreign citizens and is an important tool for ensuring the improvement of the public administration system. Practical and theoretical aspects of the Egovernment system are developed in three directions: S2C (state citizen), S2B (state to business), S2A (state to state authority), S2F (state to foreign citizens).

The biggest step in creating a legal framework for the functioning of egovernment is the adoption of the Law "On Electronic Government". To date, the new Law is the key legal act to create an electronic government. The Law gives a number of important definitions. Thus, in accordance with Article 3 of the Law "On Electronic Government", e-government is a system of organizational and legal measures and technical means aimed 
at ensuring the activities of state bodies providing public services to individuals and legal entities through the use of information and communication technologies, as well as interdepartmental electronic interaction. A public service is a service rendered by state bodies in the exercise of their functions, performed at the request of applicants. The state service can also be provided by other organizations in cases when they are entrusted with the functions of rendering public services in accordance with the legislation. These definitions not only give legislative exact key concepts, but essentially enrich the scientific apparatus with the theory of information law.

The Law also defines the tasks and basic principles of e-government. Equally important is the definition of the institutional framework of egovernment in the Law. Thus, the terms of reference of the Cabinet of Ministers of the Republic of Uzbekistan and the powers of the authorized body in the field of e-government are regulated. Another significant innovation in the legislation is the creation, within the framework of the Law, of a legal framework for public services. In particular, the classification of types of electronic public services is given, it is determined that electronic public services should be registered in the Unified Register of Electronic Public Services, and also requirements for electronic public services and requirements for the request of electronic public services are legally stipulated.According to Article 23 of the Law, the Applicant, when receiving electronic public services, has the right: to receive electronic public services in a timely manner and in accordance with the approved regulations of electronic public services; to receive full and reliable information on the procedure for providing electronic public services; receive information on the progress of electronic public services through various forms of interaction (official website, telephone, e-mail, hotline and others); appeal against decisions of state bodies that provide electronic public services, actions (inaction) of their officials higher in the order of subordination to bodies or officials or to court in the established manner; participate in the assessment of the quality of electronic public services; to make proposals on the improvement of electronic public services [6].

The chapter of the Law is fully devoted to the organization of the functioning of e-government. In accordance with the provisions of the Law "On Electronic Government", the e-government infrastructure consists of: central databases; systems of interagency electronic interaction; information systems and information resources of state bodies and their complexes; official websites of government agencies and the Unified Portal for Interactive Public Services; Data processing center and interdepartmental data transmission network. 
Thus, to date, the use of information and communication technologies in public administration, in particular the introduction of the "egovernment" system is defined as the main means of optimizing management processes; information society and the formation of the system "Electronic Government" is reflected in the Constitution and more than 30 legislative acts, which include such laws as: "On Electronic Document Management", "On Informatization", "On Electronic Digital Signature", "On electronic commerce ","On electronic payments ". At the same time, an important step forward was the adoption of the Law "On Electronic Government". Further improvement of the legal framework is associated with the adoption of by-laws that ensure the mechanism for implementing the Law, as well as the adoption of new acts to ensure the security of databases, data from unauthorized intrusions.

\section{References}

1. The Constitution of the Republic of Uzbekistan. - T .: Uzbekistan, 2017. - P. 8.

2. "Critical analysis, strict discipline and personal responsibility should become an everyday norm in the activities of each leader." Report of the President of the Republic of Uzbekistan Shavkat Mirziyoyev at the enlarged meeting of the Cabinet of Ministers dedicated to the results of the country's social and economic development in 2016 and the most important priority areas of the economic program for 2017 . // http://pressservice.uz/en/lists/view/187 (visit to the site - November 5, 2017)

3. Decree of the President of the Republic of Uzbekistan on May 30, 2002, No. 3080. On the further development of computerization and the introduction of information and communication technologies. The People's word, June 1, 2002.

4. Almanac of legislation of the Republic of Uzbekistan, 2005, No. 47-48, art. 355.

5. Resolution of the Cabinet of Ministers of November 22, 2005 No. 256 "On Improving the Regulatory and Legal Framework in the Sphere of Informatization" Appendix No. 1.

6. The Law of the Republic of Uzbekistan "On Electronic Government".www.lex.uz 